\title{
Nerve abscess in leprosy: a retrospective study
}

\author{
M. K. SIDDALINGASWAMY* \& K. S. RAO $\dagger$ \\ *Department of Orthopaedics and Reconstructive Surgery, Central \\ Leprosy Teaching and Research Institute, Chengalpattu-603001, \\ India; and †Senior Orthopaedic Surgeon, Safdarjung Hospital, \\ New Delhi
}

Accepted for publication 11 May 1993

Summary Nerve abscesses occur, both in tuberculoid and lepromatous leprosy. We studied 20 patients who had undergone surgery for nerve abscess in mixed peripheral and cutaneous nerves. Details of these cases and the controversial question as to how long the question PB regimen should be continued are discussed.

\section{Introduction}

Leprosy is a disease of the skin and nerves, and the involvement of both peripheral and cutaneous nerves is often found in leprosy. Schwann cells act as a reservoir of Mycobacterium leprae. The pathology is different in tuberculoid and lepromatous leprosy. In tuberculoid leprosy there is a cell-mediated immunological reaction that causes a granuloma formation which in some cases may liquify and develop into an abscess. In lepromatous leprosy abscesses may be due to an antigen-antibody reaction, e.g. an ENL reaction, exacerbation of lepromatous lesion, necrosis of lepromatous granuloma or, perhaps, an iatrogenic reaction as a complication of perineural or intraneural injection. ${ }^{1}$ Multiple nerve abscesses are common in cases of lepromatous leprosy ${ }^{1,2,3,4,5,6,7}$ but not in tuberculoid leprosy.

\section{Material and methods}

Between January 1987 and December 1990, we carried out a decompression of the nerves of 490 patients who were suffering from early paralysis, painful neuritis and nerve abscesses. (Of these, 20 patients underwent surgery for nerve abscess.) These cases were analysed for the type of leprosy, the duration of the disease, the duration of treatment, which nerve was involved, their bacteriological index, and the assessment of sensory and motor paralysis. After the surgical evacuation of pus and the decompression of nerve, the 
pus was stained for AFB, culture, and sensitivity for pathogens was also carried out. Epineurium, along with caseation and some nerve tissue, was sent for histopathological examinations. We carried out a periodic assessment on any recovery of motor and sensory function.

The surgery involved epineurotomy and the evacuation of abscess from all nerves. Medical epicondylectomy was performed in the cases of ulnar nerve abscess and a carpal tunnel decompression for median nerve lesions.

\section{Observation and analysis}

In all, 20 patients, whose average age was $21 \cdot 3$ years (range 9-55 years) underwent an evacuation of nerve abscesses - 18 were male and 2 female. The patients had on average suffered for 1.8 years (minimum 2 months, maximum 6 years); 18 had already been on a specific treatment for between 1 month and 2 years -7 were tuberculoid, $11 \mathrm{BT}, 1 \mathrm{BL}$, and $1 \mathrm{LL}$. The skin smear was positive in only 2 cases, while the abscess material on staining showed AFB in 7 cases (including the 2 cases above). The nerves involved were 17 ulnar, 5 median, 1 lateral popliteal, the others being cutaneous nerves. The duration of abscess varied from 1 to 6 months. Culture and sensitivity of the abscess material did not reveal any pathogenic organisms. All the trunk nerves involved had some functional deficit.

\section{OPERATIVE FINDINGS}

In cases of tuberculoid and BT leprosy the pus was thick, the nerve bundles were swollen, and some were granulomatous. There was multiple nerve involvement in BL and LL cases, and the pus was thin. Tiny abscesses were found in many nerve bundles. The epineurium was thick and adhered to surrounding tissues and perineurium. It was difficult to separate the epineurium from nerve bundles.

\section{Discussion}

Nerve abscess is often seen in leprosy (Figures 1 and 2). It is more common in the tuberculoid spectrum, especially in borderline tuberculoid cases, probably due to some exaggerated delayed hypersensitivity reactions. In all, 18 patients developed nerve abscess after MDT or DDS monotherapy. Any reactions and relapses that occur during or after treatment can result in nerve damage. ${ }^{8,9,10}$ Katoch et al. ${ }^{9}$ reported a late reaction in $9 \%$ and a relapse in $13 \%$ of their cases. Pavitran ${ }^{10}$ has also reported relapses after PB regimen $(12 \%)$.

Even though nerve abscess is rarely seen in the lepromatous spectrum of the disease, many have reported nerve abscess in lepromatous leprosy. In the 2 cases reported here, both ulnar and median nerves were involved on both sides. The patients had an acute exacerbation of ENL reactions, after which they developed pain, tenderness and swelling in the nerves. The pus was thin and contained AFB and pus cells. A skin smear of the patients was positive and their BI was $2 \cdot 3$ and $1 \cdot 5$. Abscess formation was caused by an acute exacerbation of ENL lesion in the nerves.

In 5 of $11 \mathrm{BT}$ cases the pus was bacteriologically positive for AFB $(1+)$. The skin 


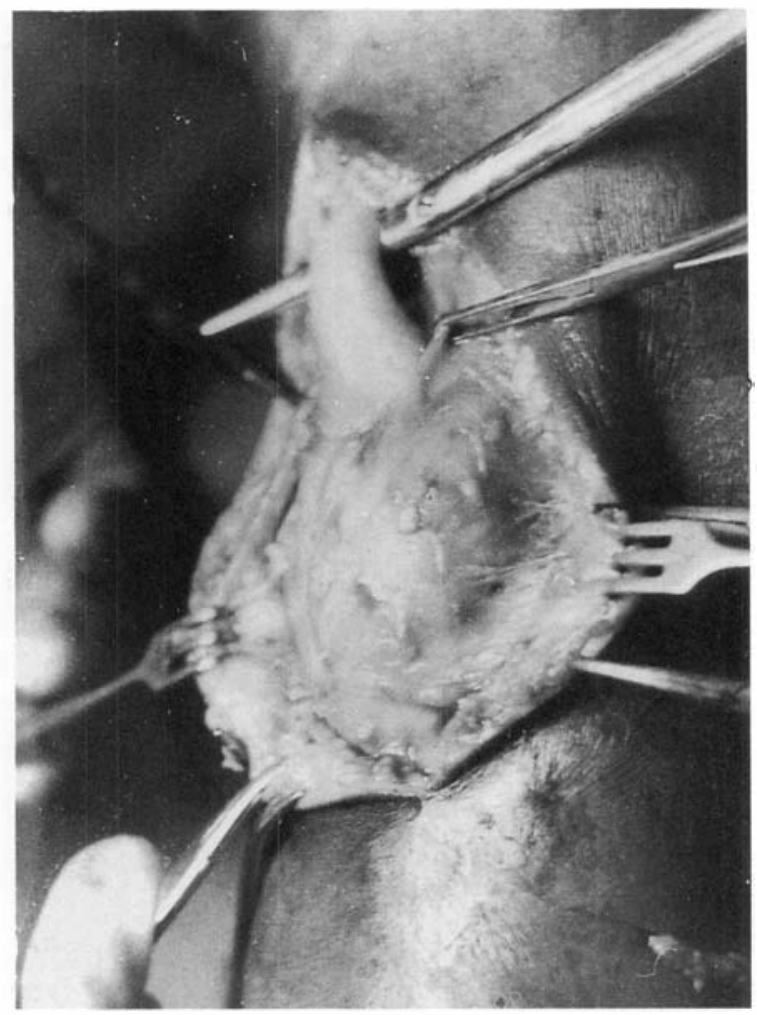

Figure 1. Photograph of an abscess in a lateral popliteal nerve.

smear was negative and skin biopsy from the patch showed a typical borderline tuberculoid type of leprosy with epithelioid cells, some lymphocytes, but no AFB were seen. Therefore, there was a discrepancy in the bacillary content of the nerve and the skin. Palande, " Sreenivasan et al. ${ }^{1}$ and Periera et al. ${ }^{12}$ have reported a discrepancy of bacterial presence in the skin and nerve lesions.

Periera et al. ${ }^{12}$ carried out some electron-microscopic studies on treated BT cases and revealed the presence of bacilli and the proliferation of Schwann cells-some were solid bacilli. Pavitran ${ }^{10}$ reported a relapse rate of $12 \%(3 / 25)$ after a PB regimen. $\mathrm{Kar}^{13}$ reported that $35 \%$ were clinically active, and $47 \%$ histologically active after 6 months of MDT in paucibacillary leprosy. Katoch et al. ${ }^{9}$ reported that $13 \%$ relapsed in paucibacillary cases after MDT. He also reported that the relapse rate fell in cases where the treatment was continued for more than 6 months. This calls attention to the controversial question of insufficient $\mathrm{PB}$ regimen in some BT cases. They have to receive treatment for more than 6 months or be treated as $\mathrm{MB}$ cases (WHO regimen). This question needs further evaluation and investigation.

Calcification can occur in caseation and necrotic material in tuberculoid and borderline tuberculoid leprosy, as a result of deposition of calcium in the dying, dead and chronically inflamed tissues. Malaviya et al. ${ }^{14}$ reported 3 cases of calcification in nerves. Ramanujam et al., ${ }^{15}$ Jopling ${ }^{16}$ and Ellis, ${ }^{17}$ reported some calcification in the nerves. In the majority of the reports, the ulnar was the most commonly affected nerve. White chalky 


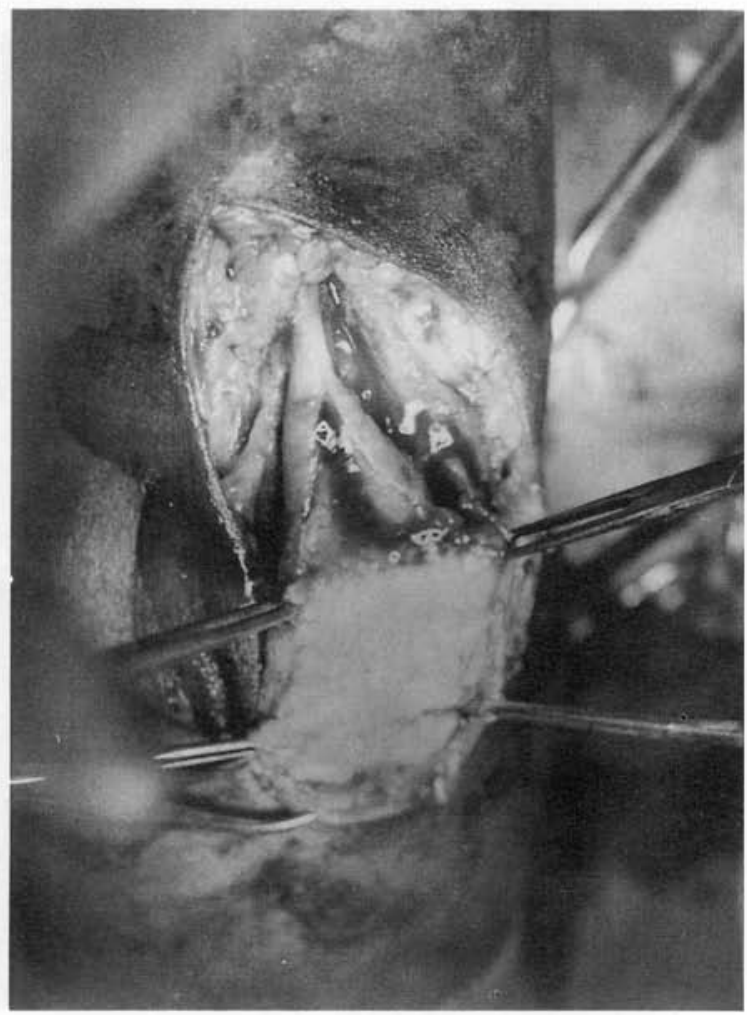

Figure 2. Photograph of an abscess which has been opened. Pus and granulation is seen.

material was found on exploration of the nerves. In our series the ulnar nerve that was thickened and painful was found to contain inspissated pus, chalky material and also a calcified stone, which was removed.

\section{Conclusion}

We found 29 nerve abscesses in 20 leprosy patients. Abscess was found in more than 1 nerve in 2 cases of lepromatous and in 3 cases of borderline tuberculoid leprosy. There was a discrepancy in the bacteriological index of the skin and nerve in 5 borderline tuberculoid cases of 11. This highlights the controversial question as to whether to continue the $\mathrm{PB}$ regimen for more than 6 months or whether the patients should receive treatment as $\mathrm{MB}$ cases (WHO regimen) to prevent any relapses. Calcification of the nerve was seen in 1 borderline tuberculoid leprosy patient, from whom a calcified stone was removed.

\section{Acknowledgements}

We wish to thank the Director of the Institute for permitting us to publish this paper, the 
Laboratory staff for staining and culturing pus, Dr Ratnakar of JIPMER, Pondicherry, for his histopathological opinion and $\mathrm{Mr} \mathrm{S}$. Chockalingam, Stenographer, for his secretarial help.

\title{
References
}

1 Sreenivasan H, Rao KS, Iyer CGS. Discrepancy in the histological features of leprosy lesion in the skin and peripheral nerves. Le pr India, 1982; 54: 275-82.

2 Browne SG. Nerve abscess in African leprosy. Lepr Rev, 1965: 65: 55-7.

${ }^{3}$ Enna SD, Brand PW. Peripheral nerve abscess in leprosy. Report of three cases encountered in dimorphous and lepromatous leprosy. Lepr Rev, 1970; 4: 175-80.

${ }^{4}$ Ghosh S, Kundu SK. Nerve abscess in lepromatous leprosy. Lepr India, 1952; 41: 11-13.

5 Job CK, Bhakthaviziam C. Nerve abscess in lepromatous leprosy: report of a patient. Lepr Rev, 1967; 38: $243-7$.

${ }^{6}$ Roy Chowdhury SB, Sreenivasan H. Nerve abscess in lepromatous leprosy. A case report and discussion of pathogenesis. Lepr India, 1977; 49: 330-8.

7 Sato S. Nerve abscess in lepromatous leprosy. Report of a case with review of reports of nerve abscess in Japan. Int J Lepr, 1956; 24: 408-17.

8 Job CK. Nerve damage in leprosy. Int J Lepr, 1989; 57: 532-9.

9 Katoch K, Ramanathan V, Natarajan M. Relapse in paucibacillary patients after treatment with short term regimen containing rifampicin. Int J Lepr, 1989; 57: 458-64.

10 Pavitran K. Relapse of paucibacillary leprosy after short term course of multi drug therapy. Ind J Lepr, 1988; 60: $225-9$.

1 Palande DD. Ulnar nerve in lower arm in diamorphous leprosy-Some observations. Lepr India, 1974; 46: $1-6$.

12 Periera JH, Palande DD, Gschmeissner SE. Mycobacterium in the nerve trunks of long term treated leprosy patients. Lepr Rev, 1991; 62: 134-42.

13 Prasad SB. Calcification of ulnar nerve abscess in a patient with leprosy-a case repo:t. Lepr India, 1982; 54: 809.

14 Malaviya GN, Mishra B, Giridhar BK, Lavanya RK, Desikan RV. Calcification of nerves in leprosy. Report of three cases. Ind $J$ Lepr, 1985; 57: 651-5.

15 Ramanujam K, Ramu G. Calcification of peripheral nerve trunk in leprosy-a case report. Lepr India, 1966; 38: 185.

16 Jopling WH. In: Handbook of leprosy, 2nd edition. London: William Heinemann Medical Books Ltd. p. 36.

17 Ellis BPB. Case report-calcification of ulnar nerve in leprosy. Lepr Rev, 1975; 46.

Lepr Rev (1993) 64, 357-61

\section{Les abcès nerveux dans la lèpre: une étude rétrospective}

\author{
M. K. Siddalingaswamy et K. S. RaO
}

Résumé Les abcès nerveux ont lieu dans la lèpre tant sous sa forme tuberculö̈de que lépromateuse. 20 sujets ont subi une intervention chirurgicale pour abcès nerveux des nerfs périphériques et cutanés mixtes. Nous décrivons ces cas et parlons de la question discutable de la durée du régime thérapeutique PB.

\section{Abscesos nerviosos en la lepra: un estudio retrospectivo}

\author{
M. K. Siddalingaswamy y K. S. RaO
}

Resumen No hay duda de que se producen abscesos nerviosos en la enfermedad de Hansens, tanto en la lepra tuberculoide como en la lepromatosa. Veinte pacientes fueron intervenidos quirúrgicamente debido a abscesos nerviosos en nervios periféricos mixtos y cutáneos. Se discuten los detalles de estos casos y la cuestión debatible de la duración del régimen PB. 